\title{
Effects of $\alpha$-amanitin on the development of mouse ova in culture
}

\author{
I. L. Levey, D. E. Troike and R. L. Brinster
}

Laboratory of Reproductive Physiology, School of Veterinary Medicine, University of Pennsylvania, Philadelphia, Pennsylvania 19174, U.S.A.

Analysis of macromolecular synthesis by preimplantation mammalian embryos in culture has revealed that activation and expression of the embryonic genome occurs in early development. The inhibition of cleavage in mouse embryos by actinomycin D (Mintz, 1964; Skalko \& Morse, 1967; Monesi, Molinaro, Spalletta \& Davoli, 1970) suggests that RNA transcribed from the embryonic genome may be necessary for continued development as early as the 2-cell stage. Because actinomycin D has been reported to exert effects not clearly related to transcriptional inhibition (Manes, 1975), its role in the suppression of embryonic development should be regarded with some caution. In contrast, the mushroom toxin, $\alpha$-amanitin, is a selective inhibitor of RNA polymerase II both in vitro and in vivo (Stirpe \& Fiume, 1967; Tata, Hamilton \& Shields, 1972; Hadjiolov, Dabeva \& Mackedonski, 1974). Preliminary reports have suggested that $\alpha$-amanitin may inhibit cleavage of mouse embryos in culture (Golbus, Calarco \& Epstein, 1973; Warner \& Versteegh, 1974), although only a relatively narrow range of $\alpha$-amanitin concentrations has been tested and only studies of embryos exposed at the 2-cell stage have provided sufficient data to establish statistical significance. To verify the inhibitory action of this drug and to establish dose-response relationships essential for analyses of messenger RNA metabolism, we have investigated the effects of $\alpha$-amanitin upon cleavage and blastulation of mouse embryos explanted into culture at several stages of development before implantation.

Embryos were collected from C57BL/6J or random-bred Swiss female mice induced to superovulate by methods described previously (Brinster, 1972). Embryos at the 1-cell, 2-cell and morulae stages were recovered from donor females at $17 \mathrm{~h}, 50 \mathrm{~h}$, and $80 \mathrm{~h}$ after HCG treatment $(10,38$ or $68 \mathrm{~h}$ after fertilization), respectively. Cumulus cells were removed from 1-cell embryos by exposure to 300 units hyaluronidase (Type IV, Sigma Chemical Company)/ml for 5-10 min. Embryos were collected from several donor females, pooled and randomly assigned to various treatment groups.

Embryo culture and exposure to $\alpha$-amanitin were conducted in $50 \mu \mathrm{l}$ microdrops of Whitten's medium (Whitten, 1971) or Brinster's BMOC-3 (Brinster, 1972), overlayed with silicone oil. Cultures were maintained at $37^{\circ} \mathrm{C}$ in an atmosphere of either $5 \% \mathrm{CO}_{2}+5 \% \mathrm{O}_{2}+90 \% \mathrm{~N}_{2}$ (1-cell stages) or $5 \% \mathrm{CO}_{2}$ in air (2-cell stages and morulae) at saturation humidity. Stock solutions of $\alpha$-amanitin (Sigma Chemical Company) were prepared in culture medium and diluted to the appropriate concentration $(0 \cdot 1-100 \mu \mathrm{g} / \mathrm{ml})$ on the day of use. Embryos were cultured in groups of 10 or 12 in the continuous presence of the drug, and examined at intervals to score continued development.

Because of their potential for development in culture from the 1-cell stage ( $P$. Hoppe, personal communication), embryos of the C57BL/6J strain were selected for use. As summarized in Table 1, exposure of one-cell embryos to $\alpha$-amanitin at various concentrations caused a dose-dependent inhibition of cleavage and blastulation. Approximately $50 \%$ of ova cultured in the absence of inhibitor developed to the blastocyst stage. Culture in the presence of $1 \mu \mathrm{g} \alpha$-amanitin $/ \mathrm{ml}$ caused a significant $(P<0.05)$ suppression of the first cleavage division, with increasingly greater inhibition at each subsequent cleavage. Greatest developmental suppression occurred in embryos exposed to. $\alpha$-amanitin at concentrations of 10 or $100 \mu \mathrm{g} / \mathrm{ml}$. These doses caused a significant $(P<0 \cdot 01)$ inhibition of the first cleavage division and prevented all development beyond the four-cell stage.

As shown in Table 2, the results with 2-cell embryos in general parallel those obtained with 1-cell embryos. Treatment with $\alpha$-amanitin caused a modest dose-dependent suppression of development to the 4-cell stage, but cleavage beyond the 4-cell stage was severely inhibited by concentrations of 
Table 1. Development of 1-cell mouse ova cultured in the presence of $\alpha$-amanitin

\begin{tabular}{|c|c|c|c|c|c|c|}
\hline $\begin{array}{c}\text { Conc. } \alpha \text {-amanitin } \\
(\mu \mathrm{g} / \mathrm{ml})\end{array}$ & $\begin{array}{c}\text { No. of } \\
\text { ova }\end{array}$ & $\begin{array}{l}2 \text {-cell } \\
\text { stages }\end{array}$ & $\begin{array}{l}\text { 4-cell } \\
\text { stages }\end{array}$ & $\begin{array}{l}8 \text {-cell } \\
\text { stages }\end{array}$ & Morulae & Blastocysts \\
\hline 0 (control) & 150 & $131(87)$ & $107(71)$ & $102(68)$ & $89(59)$ & $68(45)$ \\
\hline 0.1 & 60 & $51(85)$ & $43(72)$ & $42(70)$ & $32(53)$ & $27(45)$ \\
\hline 1 & 150 & $113(75)$ & $68(45)$ & $51(34)$ & $6(4)$ & $1(0-6)$ \\
\hline 10 & 150 & $113(75)$ & $8(5)$ & - & - & - \\
\hline 100 & 150 & $94(63)$ & $4(3)$ & - & - & - \\
\hline
\end{tabular}

Embryos were recovered from C57BL/6J mice $18-20 \mathrm{~h}$ after HCG treatment. Data represent the pooled results of 5 experiments and are expressed as the total no. of ova reaching each successive developmental stage. Values in parentheses are the \% of ova at each stage.

Table 2. Development of 2-cell mouse embryos cultured in the presence of $\alpha$-amanitin

\begin{tabular}{ccccc}
\hline $\begin{array}{c}\text { Conc. } \alpha \text {-amanitin } \\
(\mu \mathrm{g} / \mathrm{ml})\end{array}$ & $\begin{array}{c}\text { No. of } \\
\text { embryos }\end{array}$ & $\begin{array}{c}4 \text {-cell } \\
\text { stages }\end{array}$ & Morulae & Blastocysts \\
\hline 0 (control) & 108 & $105(97)$ & $99(92)$ & $89(82)$ \\
$0 \cdot 1$ & 108 & $92(86)$ & $81(75)$ & $70(65)$ \\
1 & 108 & $82(76)$ & $25(23)$ & $10(9)$ \\
10 & 108 & $78(72)$ & $19(18)$ & $4(4)$ \\
100 & 108 & $71(66)$ & - & - \\
\hline
\end{tabular}

Embryos were recovered from random-bred Swiss female mice 48-50 h after HCG treatment. Data represent the pooled results of 3 experiments, and are expressed as the total no. of embryos reaching each successive developmental stage. Values in parentheses are the $\%$ of embryos at each stage.

Table 3. Cavitation of mouse morulae cultured in the presence of $\alpha$-amanitin

\begin{tabular}{cccc}
\hline $\begin{array}{c}\text { Conc. } \alpha \text {-amanitin } \\
(\mu \mathrm{g} / \mathrm{ml})\end{array}$ & $\begin{array}{c}\text { No. of } \\
\text { embryos }\end{array}$ & $\begin{array}{c}\text { Early } \\
\text { blastocysts }\end{array}$ & $\begin{array}{c}\text { Middle } \\
\text { blastocysts }\end{array}$ \\
\hline 0 (control) & 108 & $103(95)$ & $99(92)$ \\
$0 \cdot 1$ & 108 & $95(88)$ & $90(83)$ \\
1 & 108 & $88(81)$ & $75(69)$ \\
10 & 108 & $63(58)$ & $49(45)$ \\
100 & 108 & $59(55)$ & $45(42)$ \\
\hline
\end{tabular}

Morulae were recovered from random-bred Swiss mice $80 \mathrm{~h}$ after $\mathrm{HCG}$ treatment. Data represent the pooled results of 3 experiments, and are expressed as the total no. of embryos reaching each successive stage of blastulation. Values in parentheses represent the \% of embryos at each stage. The distinction between early and middle blastocysts was based upon the relative sizes of the inner cell mass and blastocoele.

$1 \mu \mathrm{g} / \mathrm{ml}$ or greater. Only $20 \%$ of 2 -cell embryos progressed to the morula stage in the presence of 1-10 $\mu \mathrm{g} \alpha$-amanitin/ml and $<10 \%$ developed to the early blastocyst.

Cavitation of embryos explanted into culture at the morula stage was also sensitive to $\alpha$-amanitinsuppression. Approximately $40-60 \%$ of morulae cultured in the presence of 10-100 $\mu \mathrm{g} \alpha$-amanitin/ $\mathrm{ml}$ failed to cavitate, although this inhibition was not clearly dose-dependent (Table 3).

These results demonstrate that $\alpha$-amanitin is a potent inhibitor of development in the preimplantation mouse embryo from the 1-cell stage onward. In both 1-cell and 2-cell embryos, the first cleavage 
after exposure to $\alpha$-amanitin is less susceptible to inhibition than are subsequent cleavage divisions. It is undetermined whether this represents limited permeability of embryonic cells to the cyclic molecule, or an insensitivity of cells previously committed to undergo the next cleavage division. The latter explanation seems most probable to us.

It has been demonstrated that total RNA polymerase activity in the preimplantation mouse embryo increases markedly during development from the 8-cell stage to the blastocyst (Siracusa, 1973), and that this activity in vitro is inhibited by $\alpha$-amanitin (Warner \& Versteegh, 1974; Versteegh, Hearn \& Warner, 1975). Amanitin binds specifically and stoichiometrically to nucleoplasmic RNA polymerase B (Chambon et al., 1972), suggesting that its effect on embryonic development may be a consequence of a selective action on messenger RNA transcription. However, $\alpha$-amanitin treatment of mice and rats in vivo has been reported to suppress the labelling of ribosomal RNA components (Jacob, Muecke, Sajedel \& Munro, 1970; Niessing, Schnieders, Kunz, Seifart \& Sekeris, 1970), presumably by indirect inhibition of the synthesis and maturation of $45 \mathrm{~S}$ preribosomal RNA (Hadjiolov et al., 1974).

Investigation of the qualitative patterns of RNA synthesis in the mouse embryo has demonstrated that RNA synthesized by the 2-cell embryo is heterogeneous in nature, while mature ribosomal RNA components are first detected at the 4-cell stage (Knowland \& Graham, 1972). Consequently, suppression by $\alpha$-amanitin of development at the 1- and 2-cell stages, when ribosomal RNA synthesis has not yet begun, should probably be considered to result from the selective action of the drug on nucleoplasmic RNA polymerase activity. Suppression at later stages may reflect an additional inhibitory effect upon the production of new ribosomes. Subsequent investigations will study the effect of $\alpha$-amanitin on qualitative and quantitative patterns of RNA synthesis in the preimplantation mouse embryo.

This work was supported by Public Health Service Research Grant HD 08452 from the National Institute of Child Health and Human Development and I.L.L. and D.E.T. were trainees under NICHHD Grant HD 00239.

\section{References}

BRINSTeR, R.L. (1972) Cultivation of the mammalian embryo. In Growth, Nutrition and Metabolism of Cells in Culture, Vol. II, pp. 251-286. Eds G. Rothblatt \& V. Cristofalo. Academic Press, New York.

Chambon, P., Gissinger, F., Kedinger, C., Mandel, J.L., Meilmac, M. \& Nuret, P. (1972) Structure and functional properties of three mammalian nuclear DNA-dependent RNA polymerases. In Gene Transcription in Reproductive Tissue, pp. 222-246. Ed. E. Diczfalusy. Karolinska Institutet, Stockholm.

Golbus, M.S., Calarco, P.G. \& Epstein, C.J. (1973) The effects of inhibitors of RNA synthesis ( $\alpha$ amanitin and actinomycin $D)$ on preimplantation mouse embryogenesis. J. exp. Zool. 186, 207-216.

Hadjolov, A.A., Dabeva, M.D. \& Mackedonski, V.V. (1974) The action of $\alpha$-amanitin in vivo on the synthesis and maturation of mouse liver ribonucleic acids. Biochem. J. 138, 321-334.

Jacob, S.T., Muecke, W., Sajedel, E.M. \& Munro, H.N. (1970) Evidence for extranucleolar control of RNA synthesis in the nucleolus. Biochem. Biophys. Res. Commun. 40, 334-342.

Knowland, J. \& Graham, C. (1972) RNA synthesis at the two-cell stage of mouse development. J. Embryol. exp. Morph. 27, 167-176.

MANES, C. (1975) Genetic and biochemical activities in preimplantation embryos. In The Developmental
Biology of Reproduction, pp. 133-163. Eds C. L. Markert \& J. Papaconstantinou. Academic Press, New York.

MINTZ, B. (1964) Synthetic processes and early development in the mammalian egg.J.exp.Zool. 157, 85-100.

Monesi, V., Molinaro, M., Spalletta, E. \& Davoli, C. (1970) Effect of metabolic inhibitors on macromolecular synthesis and early development in the mouse embryo. Expl Cell Res. 59, 197-206.

Neissing, J., Schinieders, B., Kunz, W., Seifart, K.H. \& SEKeRIS, C.E. (1970) Inhibition of RNA synthesis by $\alpha$-amanitin in vivo. $Z$. Naturf. B25, 1119-1125.

SiRacusa, G. (1973) RNA polymerase during early development in mouse embryo. Expl Cell Res. 78, $460-462$.

Skalko, R. \& Morse, J. (1967) The differential response of the early mouse embryo to actinomycin $\mathrm{D}$ treatment in vitro. Teratology 2, 47-54.

Stirpe, F. \& Fiume, L. (1967) Studies on the pathogenesis of liver necrosis by $\alpha$-amanitin. Effect of $\alpha$ amanitin on ribonucleic acid synthesis and on ribonucleic acid polymerase in mouse liver nuclei. Biochem. J. 105, 779-782.

TATA, J.R., Hamilton, M.J. \& Shields, D. (1972) Effects of $\alpha$-amanitin in vivo on RNA polymerase and nuclear RNA synthesis. Nature, Lond. 238, 161164. 
Versteegh, L.R., HearN, T.F. \& WARNer, C.M. (1975) Variations in the amount of RNA polymerase forms I, II and III during preimplantation development in the mouse. Devl Biol. 46, 430-435.

WARNer, C.M. \& Versteegh, L.R. (1974) In vivo and in vitro effect of $\alpha$-amanitin on preimplantation mouse embryo RNA polymerase. Nature, Lond. 248, 678-680.

Whitten, W.K. (1971) Nutrient requirements for the culture of preimplantation embryos in vitro. Adv. Biosci. 6, 129-141.

Received 18 November 1976 